A. J. Harragon and G. H. Trensky, who made many of the observations.

${ }^{1}$ Covington, A. E., Proc. Inst. Rad. Eng., 36, 454 (1948).

${ }^{2}$ Lehany, F. J., and Yabsley, D. E., Aust. J. Sci. Res., (A), 2, 48 (1949).

${ }^{3}$ I'awsey, J. L., and Yabsley, D. E., Aust. J. Sci. Res., (A), 2, 198 (1949).

+ Pawsey, J. L., Nature, 158, 633 (1946)

' Martyn, D. F., Proc. Roy. Soc., A, 193, 44 (1948).

'Waldmeier, M., and Müller, H., Astron. Mitt. Zürich, No. 155 (1948).

' Smerd, S. F., Aust. J. Sci. Res., (A), 3, 34 (1950).

8 van der Hulst, F. C., Nature, 163, 24 (1949).

- Covington, A. E., Report ERB-242 NRC Canada (April 1950).

\section{GOVERNMENT AID FOR THE SOCIAL SCIENCES}

$\mathrm{T}$ WO recent issues of Planning are broadsheets on "Government Aid for the Social Sciences"*, in which Political and Economic Planning has reviewed some of the developments in this field since the end of the War. The success with which some of the techniques developed in the social sciences were used during the War, the increasing emphasis on social change, the special need in Great Britain for achieving a greatly improved rate of productivity and the realization that this depends to no small extent on improved human relations have all persuaded the Government to make increased provision for the needs of the social sciences. The first broadsheet examines the position in the universities, while the second reviews what has been done under the Research Councils, by the Departments of State and as regards the human factor in industry.

The stimulus came largely as a result of the recom. mendations of the Clapham Committee on the Provision for Social and Economic Research, which, however, as regards finance, confined its recommendations to the universities. Planning considers that the support that has been forthcoming in the past three or four years has, on the whole, been generous, and that it is no fault of the Government if, in terms of endowment and prestige, the social sciences are still the poor relations of the natural sciences. While the full effect of the increased provision cannot yet be judged, the broadsheets suggest that a critical point is now being reached and that important matters are coming up for decision which will determine the future of the social sciences for many yeers to come.

Taking as a guide the Clapham Committee's interpretation of its field as including economics and economic history, sociology, social anthropology and social psychology, political science, demography, economic and social statistics, and certain branches of medical statistics and law, Planning estimates that university expenditure on the social sciences in 1948-49 was $£ 397,008$, or $4 \cdot 2$ per cent of the total, as against $£ 115,909$ or 3.0 per cent in 1938-39. The university staff has increased from 291 in 1937-38 to 604 in 1949-50, and in 1948-49 1,057 honours degrees were awarded, or 10.2 per cent of those awarded in all subjects, as against 335 or $6 \cdot 4$ per cent in 1938-39. Mnst of the money has gone to increase the teaching staffs, and here, particularly in sociology and related subjects, expansion has been limited by the scarcity of well-qualified people. Some further expansion of

* Government Aid for the Social Sciences. (Political and Economio Planning, 16 Queen Anne's Gate, London, S.W.1.) staff still seems to be needed, and the distribution over the different subjects is still uneven.

The first question for decision is whether the earmarked grants for the social sciences should continue in the next quinquennium or whether they should be merged in the general or block grants made by the University Grants Committee to universities. Planning clearly does not consider that a reasonably satisfactory level of development has yet been reached in the social sciences for the earmarked grants to be discontinued so early. The social science faculties in each university would thereby be involved in a struggle with other faculties over the distribution of the money, in which their early stage of development might be a serious handicap and in which it might be difficult for them to obtain even the same money as before.

Attention is also directed to a further reason for giving special treatment to the social sciences. So far, the amount of new research which could fairly be attributed to the earmarked grant is comparatively small. chiefly because the universities have rightly in this phase concentrated on training the social scientists of to-morrow. This is in accordance with the priority generally recommended in the report on scientific man-power. The purposes of the Clapham Committee will not be fulfilled, however, unless more research opportunities are created, and the problem in the next quinquennium is likely to be one of finding research jobs for some of the abler students who are now being produced in greater numbers.

The universities still depend mainly on the great chaxitable foundations for research in this field, the Rockefeller and Nuffield Foundations alone providing $£ 296,000$ over periods of from two to ten years, and the Clapham Committee has urged that more money should be provided from official sources on a permanent and routine basis. Planning hopes that the universities will also seriously consider whether, if funds are insufficient to develop every side of the work, emphasis should not, during the next phase, be put on research into one of the less well-established disciplines of sociology, social anthropology and social psychology.

What matters most to the social scientist is the number of opportunities which exist for research and the use which is made of his special skill and experience and also of the results of his work. This makes necessary a review of the activities of the various Government bodies and other institutions by which the grants are made. The extent of these activities is illustrated, rather than comprehensively described, in the second broadsheet.

While the main work of the Medical Research Council falls outside the province of the social sciences, work on some aspects of physiology and psychology, especially in the fields of industrial and occupational health, provides some of the basic material about human behaviour for the social scientist. Besides the Applied Psychology Unit at Cambridge, there are the Group for Research in Industrial Psychology, the Occupational Psychiatry Unit at the Maudsley Hospital, the Sócial Medicine Research Unit at the Central Middlesex Hospital and the Statistical Research Unit at the London School of Hygiene and Tropical Medicine. The Department of Scientific and Industrial Research has recently begun to show a direct interest in the social sciences arising out of the 'operational research' approach to indus. trial problems and the encouragement given to research associations to make detailed productivity 
studies. The Advisory Council has expressed the opinion that the research associations should be free to undertake investigations, including economic and sociological studies, in any field of science and considers that the linking of physical science and engineering with economic studies within industry holds much promise for the future. The Development Commission is also able to make grants from the Development Fund for investigations and surveys of special rural problems and has already made grants for surveys of small-scale industries in country towns in various regions.

From the Colonial Development and Welfare Funds some $£ 776,000$ has been available for social science and economic research, and a Colonial Social Science Research Council has been set up to administer grants for such purposes. The Council has already established three research institutes-in the West Indies, and in East and West Africa-while the work of the existing Rhodes-Livingstone Institute in Central Africa has been expanded by a grant of $£ 100,000$ over five years. Research into economic problems affecting the Colonies is supervised and supported by the Colonial Economic Research Com. mittee. With minor exceptions the Departments of State dealing with economic and social affairs have taken little direct interest in research in this field, although some, like the Home Office and the Ministry of Health, have specific powers under recent Acts to commission or make grants for research. The recent report of the Committee on Qualifications of Planners stressed the need for the social sciences to contribute to the work of the Ministry of Town and Country Planning; but the activities of the very few research officers of the Ministry are neither properly coordinated nor, for the most part, concerned with any but short-term questions. The Ministry of Education carries out no research but has made grants of more than $£ 20,000$ since the end of the War to the National Foundation for Education and Research, which, however, is left free to plan its own research and has an income of $£ 8,000-9,000$ a year, chiefly from corporate subscriptions.

Of the work of the so-called 'economic' Departments, including under this head the General Register Office, the broadsheet remarks that the immense amount of work of interest to the social scientist is handled by the Departments concerned rather as technical processes than as research jobs. One particular project mentioned is the study of industrial location which, in 1948, the Industrial Location Division of the Board of Trade invited the National Institute of Economic and Social Research to undertake. There are also the various Commissions, such as the Monopolies Commission and the Royal Com. missions on Population and on the Press, which have instituted extensive inquiries, and the Government Social Survey, which was established in 1946 as a permanent part of the machinery of government, is also participating in the wider research field. The Committee on Industrial Productivity, set up in December 1947, was given a Panel on Human Factors affecting Productivity; and, although the parent Committee has now been dissolved, the work of the Panel is being continued, divided between the Medical Research Council and the Department of Scientific and Industrial Research.

The general conclusion reached by Planning in these broadsheets is that the work being carried on in the social sciences has so far been more impressive in scale than in quality. Some concern is expressed that the expansion of the teaching facilities in the social sciences at the universities will not of itself attract a sufficient proportion of the best undergraduate material or provide adequate research opportunities for the newly trained people. There are also many social and economic problems which still await systematic investigation. The independent research institutes have also an essential contribution to make to the advancement of research in the social sciences, particularly on more 'applied' problems and where team-work by people trained in different disciplines is required. The administration of funds in support of such institutes would be more conveniently conducted by a Social Science Research Council, and Political and Economic Planning suggests that the establishment of such a Council should be reconsidered in the light of a full and critical examination of the work and needs of these research institutes. Finally, the broadsheet welcomes the decision of a representative group of social scientists to establish a new professional association to bring together all those who are interested in the scientific study of society and to undertake the various functions appropriate to an organization with this object. Such a body should have an excellent opportunity of raising the standards and the prestige of the particular social sciences with which it will be concerned.

\section{FUTURE OF THE OVERSEAS FOOD CORPORATION}

SINCE the second annual report of the Overseas $\checkmark$ Food Corporation was issued last autumn, both the Corporation and the Government have accepted, in their main essentials, the recommendations in the report of the Kongwa Working Party for restriction of cultivation over the next three years to about 12,000 acres. These recommendations were also taken into account by the Corporation in preparing a revised long-term plan for the East African Groundnut Scheme. This plan has now been issued as an appendix to a White Paper on the Future of the Overseas Food Corporation* in which the Government announces its decision to write off the $£ 36$ millions already expended on the scheme and to transfer to the Colonial Office the responsibility for the revised plan which is now regarded as a scheme of large-scale experimental development to establish the economics of clearing and mechanized, or partly mechanized, agriculture under tropical conditions. Even on the modified basis now proposed, the scherne cannot fail to be an important contribution to the economic development of Tanganyika, and the results of the experiments being undertaken may be of value in many other tropical territories.

The Corporation's new proposals cover a period of seven years up to 1957. They envisage no further land-clearing at Kongwa or Urambo after the end of 1950. Of the 90,000 acres cleared at Kongwa, about $\mathbf{2 4 , 0 0 0}$ acres are to be set aside for agriculture, of which 12,000 will be under crop each year, the remainder of the cleared land being available for grazing. The object is to conduct fully costed fieldscale trials on a limited acreage for three years, when a further review will be made, in the light of the

* Overseas Food Corporation. The Future of the Overseas Food Corporation. (Cmd. 8125.) Pp. 20. (London: H.M. Stationely office, 1951.) 9d. net. 